\title{
The Healing Art-I
}

\author{
Legends and Lore of Its Genesis
}

By Raymond Crawford, M.A., M.D., Oxon. Physician to Kings College Hospital, and King George Military Hospital, London; Fellow of Kings College, London

WE are apt to regard the history of medicine as a development of only modern growth; yet, if we look carefully into the oldest extant literature, we may see that even then the mind of man was occupied in speculation as to the origin of the art of medicine and in attempts to explain its progress to the stage at which he found it. Thus in the Rij-Veda we find the prevalent belief in the divine revelation of the art tempered by the assertion that in the foodstuffs and of medicinal simples animals were the preceptors of mankind. If we then pass on a thousand years to what we may call the threshoid of scientific medicine, we shall find a Hippocratic treatise devoted to establishing the position of medicine as a natural corollary of dietetics. So early may we discern a strain of rational empiricism leavening
the lump of theurgy and superstition, that bids fair to the lump of theurgy and superstition, that
occupy the whole arena of early medicine.

We' see, then, that ancient literature recognized three springs of medical knowledge - a divine source, an animal source, and a human source-and I propose to advert consideration on some future occasion.

BELIEF IN DIVINE SOURCE OF MEDICAL KNOWLEDGE

Hindoo Medical Legend.-Hindoo medical legend affords a typical account of the divine exposition of medical knowledge, and of its transference to mankind. Like the Nahuans of ancient Mexico, the Hindoos recognized four successive ages in their chronology. In the first age mankind remained virtuous, happy, and free from disease, for had not Brahma, the supreme creative being, given him the four immortal Vedasthe Rij, Yajur, Sama, and Atharva-containing all the knowledge required by mankind during the first age. It should be remarked, in passing, that these Vedas, replete as they are with samples of curative, as well as of preventive medicine, belie an origin in an age exempt from all disease. In the second age man fell away from virtue and disease appeared, to the curtailment of life and the impairment of memory. In the third age half of the human race was given over to depravity. In the fourth and present age the moral and physical corruption of man grew apace, so that disease flourished exceedingly. These four ages approximate closely to the four Biblica epochs of the primordial bliss of Eden, of the fall of Man, of the state of the earth before the Flood, and of the age that followed thereafter. Such compassion had Brahma for man's suffering in this fourth age that he produced a second class of books called Upavedas, or supplementary Vedas, one of which, the Ayur-Veda, was intended to teach the right manner of living, and the prevention and cure of disease, so that man might live happily in this world, in preparation for further happiness in afuturestate.

The Ayur-Veda, or Science of Life (ayur=period of living; ved = to know), is a sacred medical record of high antiquity, maintaining the general outline of the yet older Atharva-Veda. It shows that medicine in ancient India Atharva-Veda. It shows that medicine in ancient India
was part and parcel of theology, and that the same priests as controlled religion controlled also the treatment of disease; it was not till the end of the Vedic period that the physician began to shake himself free of priestcraft and to assume an independent individuality. Fragments only of the original Ayur-Veda survive, preserved in the Shastres or Commentaries on the Vedas. It is said to have consisted of 1,000 sections, each of 100 stanzas. The divine Brahma, with truly human insight, realizing the impossibility of learning so large a work, provided an abridgment in eight parts. Nowadays, such is the quality of mercy, that when a System of Medicine is published in no more than seven volumes it is accompanied by an abridgment in one. Divine exponents are the first to handle these divine books of healing in a celestial entourage. Brahma, so say Charaka and Susrata, first instructed the god Dakhsa, the Prajabati, in the Ayur-Veda. This god compiled a book, the Chikitra-Darshana, which he communicated to the two Ashwins, or offspring of Surja, the Sun. These Heavenly Twins became the medical attendants of the gods, on whom they performed miraculous cures, and authors also of important medical works. Indra, King of Heaven of important medical works. Indra, King of Heaven,
was so impressed by their wonderful cures that he induced was so impressed by their wonderful cures
them to instruct him in the Ayur-Veda.

Various legends exist telling of the transference of medical knowledge from heaven to earth. One relates how the Munis or sacred sages, grieved at the melancholy $*_{\text {A }}$ presidential address delivered before the section of the History of Medicine of the Royal Society of Medicine, reported
in The Lancet. spectacle of disease, met in council in the Himalayas and decided to ask the help of Indra, to whom in heaven the sent one of their number. Indra duly instructed their emissary in the Ayur-Veda, and on his return he related to the Rishis, or sages, the principles committed to him. In the strength of this knowledge the Rishis succeeded in living in happiness and health to extreme old age wrought many cures on men, and wrote valuable wórks on medicine. Foremost in skill was Agnibesà, who in structed practitioners on earth, as the Prajabati did in heaven. Agnibesa's treatise was amended later by Charaka.

The number of different gods associated with healing in Hindoo mythology is due to the readiness with which, in India, one god supplanted another in popular favor.

One other Hindoo legend calls for mention, if onl because it recognizes the association of the serpent with medicine; in view of the prevalence of serpent worship in ancient India it is remarkable that more is not heard of it in Hindoo" myth. The legend runs ${ }^{1}$ that " the Veda were lost in the deluge, but were recovered by the great serpent Ananta. At the churning of the ocean by the gods and demons the water of the ocean was converted into milk, and then into butter, from which precious gift were derived. Among these was Dhanwantari, the physician, or holy sage, the possessor of the water of lif drunk by the immortals." Indra instructed Dhanwantari, in heaven, in the Ayur-Veda, so that he practised medicine with great success among the gods. But seeing the many maladies and the misery of mankind $h$ came on earth to cure them. As king of Benares his miraculous cures gained such fame that the divine sage resolved to solicit his aid; Susruta was chosen to be the one instructed by him. To the conservative sentimen of Dhanwantari the Ayur-Veda seemed all-sufficing, but so voluminous that he charged Susruta to abridge and arrange it for easier comprehension. Dhanwantari began by expounding surgery, as formerly there were no disease among the gods, and only wounds required treatment his exposition is contained in the six books of Susruta which seem to have been committed to writing about $500 \mathrm{~A}$. D. The Commentaries of Charaka and Susruta supply the groundwork of the more recent systems of physicians, those of Susruta surgeons.

The Vedas present the usual blend of prayer and invocation, of magic and spells, familiar in primitive medicine but through all this flows a thin stream of rational empiricism, touching, on the surgical side, such procedures as the extraction of arrows, the dressing of wounds, amputation of legs and their replacement by iron substitutes, castration, and removal of eyes; and on the medical side the action of numerous herbs and the healing power of water. The oldest, the Rij-Veda, mentions no less than 1,001 drugs, of which 760 wer herbs. Vedic physicians lived as herbalists in house surrounded by gardens of medicinal herbs, but they wer instructed to seek knowledge also from shepherds and huntsmen, no doubt in the belief that they in turn. will have learnt much from animals. It is noteworthy that many of the instruments described by Susruta are constructed after the form of beasts and birds. The anatomical knowledge of the Vedas is of the most elementary kind, and consists in little more than an enumeration of the chief component parts of the body, while their physiology stagnates in the expa breath as the source of vital power.

Greek Le'gend: Asclepius. No good purpose would be served by multiplying illustrations of the doctrine of the divine revelation of medicine from the records of Egypt, Assyria, Persia, Judæa, and other nations; in essence, they are everywhere alike. Greek legend, however, wil repay fuller consideration, for the study of origins serve to throw light on its traditions and symbolism.

Among the gods of Greece, Apollo, son of Zeus and Leto, is the doyen of healers, while under his guidance Pæon ministered to the medical needs of the gods in Olympus. Other gods and goddesses are endowed with some share of the faculty of healing; thus, both at Athen and Epidaurus Athena bore the occasional surnam "Health," and Asclepius was said to have received from Athena the blood of the Gorgon; that from the veins on the right side he used for the healing of men and the restoration of life, that from the veins on the lef $t$ for their destruction. Asclepius is the medium by which Greek medicine came down from heaven to earth. In the ${ }^{1}$ T. A. Wise: Hindu System of Medicine. earlier legend he stands out as a medical superman, and only later does he assume complete divinity. He was the son of Apollo and Coronis, who was slain by Artemis committed to Apollo. As her body was about to be the child Asclepius (whether by artificial abortion or by Cæsarean section we are not told), and gave him to Chiron, the Centaur, to instruct in the cure of diseases. One legend has it that Chiron acquired his knowledge from Apollo and Artemis; another, from his own observation and experience, gained while hunting on Mount Pelion. Hunters, as we have seen in Hindoo myth, were believed to enjoy special facilities for acquiring such knowledge; certainly acquaintance with the favorite foods of animals must have facilitated approach, and the baiting of traps and pitfalls. Homer ${ }^{2}$ tells us that it was Chiron who instructed Achilles in the cleansing and healing of wounds, and Achilles transmitted his teaching to his friend Patroclus. Pindar ${ }^{3}$ attributes the use of charms as well to Chiron. So great was the skill of Asclepius, that we find Castor and Pollus, the Greek Heavenly Twins, insisting on his accompanying the expedition of the Argonauts. Ultimately he acquired the power of restoring the dead to life, but this achievement proved his undoing, for Pluto, in alarm for his kingdom, complained to Zeus, who slew him with a behind him two cast him down to Hades. He left least four daughters, Hygieia, Panacea, Egrea, who married a serpent and was changed into a willow. and Jaso; from which of these Hippocrates, who was reputed to be a descendant of Asclepius, was derived, we are not told. The exploits of the warrior surgeons, Podalirius and Machaon, are recounted by Homer, and to his record we need only add, that to Podalirius was attributed the discovery of the art of bleeding. On his return from Troy he was driven by a storm to the shores of Caria, where a shepherd, learning that he was a physician, took him to the king, whose daughter was sick. He is said to have cured her by bleeding her from both arms, while
for his fee he received his patient in marriage, along with a rich grant of land.

Asclepius was represented in Greek art with a serpent twined round a staff; a dog and a cock not infrequently figure among his emblems; on a coin of Epidaurus a dog lies beneath the throne on which he is seated. The cock is his habitual offering of sacrifice, and there a re the inevitable legends to explain both serpent and dog. Asclepius, it is said, was shut up in the house of one Glaucus, who had sought his aid; while he was deep in thought there came a serpent, carrying an herb in its mouth, and twined itself round his staff. Asclepius killed the serpent, and used the herb to restore the dead to life. The presence of dogs in the sanctuary of Asclepius was explained by a legend that, when an infant, he was suckled by a bitch. According to an inscription found in the temple of Asclepius at Peiræus the dogs were fed on the sacrificial cakes. If we may credit Sextus Empiricus," the flesh of these sacred dogs was given to the patients to eat as medicine. As we shall see presently, the dog was credited with imparting to man knowledge both of herbs and of the healing of wounds; may be, then, its flesh was at one time eaten sacramentally, as embodying the god of healing. There was another legend that Asclepius had been suckled in infancy by a goat, and Pausanias blends the two legends into a story of his being suckled by a goat and guarded by a dog. According to સlian, dogs, goats, serpents, oxen, and pigs have the power of foreseeing an impending epidemic; it is perhaps worthy of note that three of these animals figure in the legends and symbolism of Asclepius. Inscriptions found in the temples of Asclepius record the healing of blindness by dogs licking the eyes, and the cure, by licking, of a tumor on the neck of a boy. Other gods of healing, for instance, the Sumerian Gula and the Babylonian Marduk, are represented accompanied by a dog.

The Serpent in Relation to Healing.-The association of Asclepius with the serpent is of very great interest and importance. The association is not peculiar to him, for his Phønician counterpart, Eshmun, likewise has a serpent as his symbol; so has his own daughter, Hygieia, who is represented feeding a serpent from a saucer. In Madagascar, too, Ramahavaly, the god of healing, was held to be the patron of serpents and to employ them in his service, for good or for harm. When his image was ${ }^{2}$ Iliad, XI., 827 'EPyth., $111 . \quad$ Bekker, p. 174

sNat. Anim., VI., 16 
carried in public, each of his attendants held a writhing serpent in his hand, to inspire awe in the beholders. The Naga (serpent) tribes of Cashmir acquired their medical skill from the serpent, and the ancient Celts by drinking serpent broth. In India it is common to make clay or brazen images of the serpent, and offer sacrifice to them on behalf of the sick, just as Moses in time of pestilence set up a brazen serpent, that all might behold and be cured. The inhabitants of . Southern Arabia regarded medicinal waters as haunted by serpent jinn, and in a certain African lagoon dwelt a serpent that and in a certain African lagoon dwelt a serpent that
relieved madness, and in an Algerian well one that cured relieved madness, and in an Algerian well one that cured
sore eyes. There was a prevalent belief in the Middle Ages that the household snake, if not propitiated, would prevent conception.

In the legends of Asclepius we have already encountered the belief that the serpent has knowledge of herbs that can restore the dead to life, and we meet it again in the story of Polyidus. The same belief is current in German, Italian, and Lithuanian folk-lore. A Syrian story ${ }^{6}$ tells how the king of the serpents restored three slain men to life by washing them with the waters of life; and Russian folk-lore represents the serpent as possessing a magic water that heals all wounds, restores sight to the blind, and vigor to the cripple. One Russian tale describes a wonderful garden, in which were two streams of healing and life-giving water, and round it was coiled a serpent. In Eden the serpent knew well the properties of the Tree of Life.

Sacred snakes were kept in the temple of Asclepius, and fed with honey-cakes; at Epidaurus certain native snakes were sacred to Asclepius. The temple snakes were credited with effecting cures by licking patients with their tongues. Similârly the blind emperor Theodosius their tongues. Similarly the blind emperor Theodosius
received his sight by a serpent laying a precious stone received his sight by a serpent laying a precious stone
on his eyes, and Siegfried becameinvulnerable by bathing in the blood of the dragon.

Besides the tales of miraculous cures by serpents, there is a crop of legends that seek to explain how man acquired the healing knowledge of the serpent. The serpent, by touching his ears or his lips, makes him to understand the voices of birds, who have the gift of foretelling the future, and the language of plants, so that they disclose to the hearer their secret medicinal properties. That serpents should know the language of birds wa not unnatural, for they were believed to be generated

from the blood of birds; this idea may be referable to the fact that serpents eat the eggs of birds. Yet another widespread belief held that the medical skill of the serpent could be acquired by eating its flesh; this is merely an illustration of the general belief that the properties of animal, man, or god may be acquired by eating the possessor.

Cicero says that the ancients explained the connection of the serpent with Asclepius by the fact that, like the healing art, the serpent yearly sloughed its old skin and put on a new; but, in all probability, Asclepius was originally himself a serpent that subsequently became transformed into an anthropomorphic god, for whom conservative religious sentiment preserved the symbol of the serpent. This same conservatism is seen in the custom of sending a sacred snake from an existing sanctuary whenever a fresh one was established. It is not clear why the serpent is represented twined round a staff, just as it was coiled round an apple-tree in the garden of the Hesperides. Can this, too, be a symbol?-a symbo of some tree-spirit standing yet further back than the serpent in the pedigree of Asclepius?

Zoologists tell us that the serpent is by no means an intelligent animal, despite the fact that it became the legendary embodiment of knowledge, and of medical knowledge in particular. The serpent of Genesis was more subtle than any beast of the field. The strange sinuous form, the mysterious gliding movement, the annual sloughing of the skin with its annual renewal, the weird fascination of its victims - all these must have served to endow the serpent with the homage of wonde that attaches, of ten so inaptly, to the unknown; and perhaps the deadly poison of the almost imperceptible bite may have seemed to link it appropriately to the science of herbs, that bring life or death to man.

BELIEF IN ANIMAL SOURCE OF MEDICAL KNOWLEDGE

From this brief consideration of the serpent, to the ancients so much more of a god than an animal, we may pass to the kindred belief that man owed his knowledge of medicine to observation and imitation of the practices of animals.

The Dog.-From the evidence of geology we know that the dog was the first animal to be domesticated, and man must have soon observed its habit of licking its wounds, as cats and horses also do. He must have noted again and again how much more readily his dog' sores healed than his own, and not unreasonably at
tributed this to the licking. It is no matter for surprise then, that we should find this method of healing wounds oFrazer: Pausanias, II., x., 3. employed in the temples of Asclepius by the tongues of
dogs and of serpents. In quite recent years licking of sores by the tongue of a dog was held in repute both in Scotland and France. ${ }^{7}$ In the absence of any knowledge of the essential conditions that govern the healing of wounds, it was a natural conclusion that the licking wa of therapeutic intent, and akin to the cleansing that was the central feature of the primitive treatment of wounds There is no certain evidence that licked wounds of dog heal more readily than those which cannot be reached by licking; and the contrast with the slower healing in man would seem to be due to the wide difference in immunity to sepsis between man and dog, for the dog highly refractory even to subcutaneous injection of pyogenic organisms. There seems no reason to suppos that by licking their wounds dogs imbibe toxins that produce specific antibodies which assist them in th struggle against invading organisms, for they appear to have little or no need of such assistance. When on reflects how a child sucks an injured finger; how he put his hand to a hurt leg or a bruised head; how hard each one of us finds it to keep his fingers from a scab, it seem not improbable that underlying all these tendencies i a common instinct to touch the injured part with the tongue or hand to determine the injury and, if possible to remove the cause. If, in the case of the tongue, this should promote healing by the removal of dust an particles of dirt, this contingent benefit is merely inc dental and does not indicate a definite therapeuti purpose.

There is a very ancient tradition that dogs, when they are ill, eat grass or standing corn to relieve the stomach by vomiting and purgation, and Elian $^{8}$ says it was from this that the Egyptians gained their knowledge of purgatives and emetics. Aristotle says that wolves do the same, and he might also have included cat Elian adds that dogs relieve themselves in this way of worms and of the excess of bile which causes rabies The grasses that dogs eat have been identified as Triticum caninum (dog-wheat), Agrostis canina (brown bentgrass), and Cynosurus cristatus (dog-grass). From observation of my own and other dogs I feel sure that dog do not eat grass, exclusively or even chiefly, when the are sick, and certainly not with the purpose of excitin vomiting or purgation. They are most prone to eat grass immediately on reaching green fields after a spell of town life; as a rule they cease to eat it, or do so ver rarely, after a few days in the country. I have never seen the grass produce actual vomiting; it is usually hawked back, churned up with saliva, and has probably seldom passed far down the gullet. When not regurgitated I have never known it to cause diarrhœa; any
looseness of the bowels is referable to the increased exercise that the dog takes in the country as compared with a town. The number of human beings who che grass-bents is quite as large as that of dogs that chew grass, and I have an impression that the habit is far more common among town-dwellers visiting the country than among country-folk. The human being certainly chew it because he likes the taste, and avoids swallowing for fear of exciting vomiting. I strongly suspect that there is some subtle aroma of the grass that tickles the dog's palate, and seeing how much misery a dog suffer in the prospect and act of vomiting I am loth to believe that it entertains any therapeutic purpose.

\section{VENESECTION}

The origin of venesection was another matter that excited speculation in the ancient world. Pliny ${ }^{9}$ says that the hippopotamus invented blood-letting and taught the art to man. This animal, he says, when surfeited with blood, seeks out the sharp point of a newly-cut reed, and pressing against it, opens one of the veins in the thigh, to its immediate relief; then it plaster the wound over with mud. Buffon, quoting P. Labat, repeats the story, substituting a sharp-pointed rock for the reed, and with the picturesque addition that the animal agitates its body to promote the flow, and when it thinks it has lost a sufficient quantity rolls in the mu so as to close the wound. With respect to the variou observations involved in these statements, it is the case that the hippopotamus is very prone to exhibit wounds, in spite of the fact that in most parts the skin is two inches thick. These wounds seem to arise in two ways: most commonly as the result of fights, as male hippopotami in the wild state are constantly fighting, regardless of the pairing season, and a wounded animal is often furiously attacked by a comrade; but also as the result of rubbing themselves against any convenient projection a habit that is common among animals in confinement, and even among such domesticated animals as cows, sheep, and pigs. Again, it is a habit of both hippo'Gregor: Folk-lore of the North-East of Scotland, p.
D'Tharace: Erreurs Populaires et Propos Vulgaires, ii., 178. AAElian: Anim. Nat., V., 46; VIII., 9. Pliny: N.H., XXV, 51

'N. H., VIII., 40, and XXVIII., 31 . potamus and rhinoceros to roll in the mud of river-banks ill they are plastered all over, and the mud would ertainly adhere more readily to the abraded surface of a wound, giving the semblance of a purposive dressing of mud. The Andaman Islanders use mud in similar fashion as a protective covering, as some think to guard them from the attacks of mosquitoes; but this is probably only part of the truth, as mud is used as a dressing in countries where there are no mosquitoes, probably for no better reason than that it is always handy. In the case of the-Andaman Islanders, dwelling as they are almost on the equator, it is more likely used as a protection against the direct rays of the sun. It is not without interest, in considering the association of the hippopotamus with venesection, that the hippopotamus is one of the animals that has a colored sweat, carmine $\mathrm{n}$ its case.

The vampire bat has shared with the hippopotamus the credit of having taught mankind the art of venesection; such was the belief of the natives of Peru at the time of the discovery of that country. Peter grievously stricken with pleurisy by the agency of one of these bats, after the human phlebotomist had failed to strike blood. Buffon cites several travelers who assert that large vampire bats suck the blood of men and cattle when asleep; they were believed to render the victim insensible to their bite by agitating the air with their wings and throwing him into a deep sleep. Doubt was thrown on these observations till Darwin, in his "Voyage of the Beagle," described how he actuany saw a vampire bat sucking blood from the withers of one of the camp horses. These bats attack man less frequently than cattle, and usualiy when asleep and on an exposed foot. They have a capricious taste, for while one person may sleep in the open air with pertect immunity, another will be bitten almost nightly. This trait is common among blood-sucking animals, such as fleas and lice; whether it is due to difference in the blood, or to the relative thinness of the skin, or to some other cause is abscure. Females, on the whole, seem to be more susceptible to both lice and fleas than males, and I can testify that not one of the least blessings conferred on myself by a long period of connubial felicity has been complete immunity to fleas. The habitual food of these bats is insects, and blood is a prized but infrequent luxury. It is popularly believed in Peru that bites sometimes prove fatal, as the blood continues to flow after the bat has relaxed its hold; may be that, like the leech, it secretes an albumose in its saliva. J. G. Wood says that the wound is sore and inflamed, but never fatal, but he appears to base this conclusion on an estimate of the amount a bat can

Charleroix," in his "History of Paraguay," refers the discovery of blood-letting to the anta, an animal, "who, when he finds himself overstocked with blood, opens one of his veins with the point of a reed." The anta is the South American tapir, which Linnæus described as a sort of terrestrial hippopotamus. Lyddeker says that their hides are of ten thickly plastered with mud, probably as a protection against insects, and he adds that they are often found wounded by the claws of jaguars, which are their worst foe; these circumstances taken together show how this legend may have originated.

Yet another ascription of the art of bleeding is to the leech, of which Pliny says ${ }^{12}$ : "The action of leeches is looked upon as pretty much the same as that of the cupping-glasses used in medicine, their effect being to relieve the body of

$\mathrm{He}$ is a bold man that would venture to assign to any individual, man or animal, the honor, if such it be, of having introduced venesection into medicine; but we must not forget that it may well have originated out of all connection with medicine, as a part of primitive ritual, and that its place in medicine may be merely that of an ancient ritual survival. There is a welldefined stage in the evolution of sacrifice, at which, instead of sacrifice of the man himself, blood only is taken from him, and his life is spared. He is brought to the altar and gashed by the priest. A modification of this is met in the worship of the Phrygian Attis, where the priest draws blood from his own arm and presents it as an offering to the god; he is both priest and victim. In later stages an animal and then an animal's blood is substituted for a man and a man's blood, and later still a plant or the juice of a plant, for red wine is the blood of the plant.

Human sacrifice and ritual cannibalism seem to have reached their zenith among the ancient Mexicans. The ordinary mode of sacrifice was for the priest to slash open the breast and tear out the heart, then to fling the corpse to the worshippers to feed on in their homes. But at

${ }^{10}$ De Novo Orbe, Decade 8, ch. vi., p. 30.

"Lettsom: History of the Origin of Medicine. 
many of their religious fasts it was customary to draw blood from ears, eyelids, nose, lips, arms, legs, and body by thrusting the thorns of aloes into their veins and by passing sharp sticks through the tongue. With such practices prevailing among the priesthood, and with medicine in their hands, one may discern a portal by which blood-letting may have found its way into medicine.

The rationale of ritual blood-letting lies in the belie that the soul and the life of man reside in his blood. Even Harvey regarded the blood as the seat of the soul, and we find him in his Prælectiones refuting Aristotle who had asserted the primacy of the heart, and laying it down dogmatically that the "soul is the blood." By eating the flesh or drinking the blood of the victim the worshipper eats the body or drinks the blood of the god, for by the act of sacrifice the victim becomes one with the god; the desire for complete union with the god, by commingling with his substance, is a dominant feature of early worship. The gods themselves are constantly rejuvenated by the blood of sacrifices, so that they may perform with unimpaired activity the vitally important functions incumbent on them. The Mexicans and Nicaraguans used to make effigies of their gods out of meal kneaded with human blood and devour them sacramentally. Blood was also used as a medium of divination, the Babylonian physicians drawing important conclusions from the behavior of the blood drawn in blood-letting. It is interesting to find modern pathologists adopting hæmatoscopy afresh, as a means of divining morbid conditions of the subject.

Whatever the origin of blood-letting, we find the practice firmly established anterior to the earliest medical literature; though not mentioned by Homer, it was wel known to Hippocrates, and was an habitual remedy in veterinary medicine in the time of Vergil. ${ }^{13}$

\section{isorDers of vision}

A rich crop of legend grew up around the propertie and disorders of vision. Men were puzzled by the closed eyelids of the young, and suggested various explanations of the mode by which they acquired sight. Pliny ${ }^{14}$ says that puppies are born blind, and that the length of time before they acquire sight depends on the amount of mother's milk; so that the more numerous the puppies the later do they acquire it. In another passage ${ }^{15} \mathrm{~h}$ states that the swallow employs celandine as an eyesalve to give sight to her young, and that it can restore vision even when the eyeballs have been plucked out. The plant blossoms, he informs us, at the time of the swallow's arrival and withers at its departure. Probably it is from these facts, approximately correct as they are, that it acquired its botanical name "chelidonium," from the Greek $x$ incicis = a swallow. Pliny recommends its juice blended with Attic honey as a sovereign remedy for films of the eyes, and its virtues have been perpetuated in the use of the term "chelidonia" for eye-salves. The almost dazzling brilliance with which the flower in early spring peeps out from its sombre green cushion of leaves may well have suggested its sympathetic usefulness for dim eyes. Pliny ${ }^{16}$ asserts categorically that it was from the swallow that man learnt the use of celan dine for affections of the eye, while Elian regrets that all their labor to prepare such an eye-salve as swallows use has been in vain.

Hawkweed also enjoyed high repute in diseases of the eye. Pliny says that the hawk distils its juice into her eyes to prevent any dimness of vision, and mixed with human milk he recommends it as a cure for all diseases of the eye. It was necessary to postulate the employment of some such specific remedy to explain the marvellously keen sight of the hawk's eyes. Elian $^{17}$ has it that "physicians use this same remedy for eye diseases, nor do they deny that they have learnt it from birds, but prefer to profit by the knowledge."

Fennel, too, stood high in favor in the treatment of diseases of the eye. Both Elian and Pliny ${ }^{18}$ were awar of the fact that when a snake changes its skin the disk over the eyes peel off with the rest, and appear as dry lenses in the slough. Pliny seems to say that the snake takes fennel internally to aid exfoliation, and also applies it locally to the eyes to sharpen its sight, and it was this knowledge that led to its use by man as an eye-salve. knowledge that led to its use by man as an eye-salve. but according to the doctrine of signatures, as it has black spot on its corolla, resembling the pupil. When Michael in "Paradise Lost" opens the eyes of Adam to see the future of the world and of its own progeny therein, he

$$
\begin{aligned}
& \text { purged with euphrasie and rue, } \\
& \text { aal nerve, for he had much to see }
\end{aligned}
$$

And from the well of life three drops distilled.

${ }^{13}$ Georgics, III., 457, seq.

${ }^{14} \mathrm{~N}$. H., VIII., 62.
${ }^{15 I b .,}$ XXV., 50.

18Ib., IX., 16; and N. H. VIII., 41, and XX, 95.
Ambroise Paré asserts that the operation for cataract was discovered by means of a goat with a film overlying the pupil tearing off the film accidentally when scratching itself against a thorn, and in consequence recovering its sight; but Elian and Pliny ${ }^{19}$ reject the accidental character of the goat's discovery. Pliny says that the female goat uses the point of a bulrush and the male the thorn of a bramble for its manipulations, but neither he nor Elian appreciates the nature of cataract, as Pliny conceives that the cure is due to escape of blood that has surcharged the eyes, and Elian to the escape of some morbid humor.

The phenomenon of nyctalopia in man was known to the ancients, and goat's liver was eaten for its cure, as by day; but in the discussions of the non-medical writers by day; but in the discussions of the non-medical writers
of antiquity there already exists a confusion as to the meaning of the term, some taking it to mean "able to see only at night," and others " not able to see at night." It is an interesting example of the widely prevalen organo-therap of early medicine.

\section{Self-Induction, the Movement of the Earíh, and the Æther}

WHEN a wire is moved in a magnetic field, an electric current is induced in the wire. The observation does not teach the experimenter anything as to any influence of the motion of the earth with respect to the æther The case of self-induction looks different. The carriers of an electric current flowing in a wire, Dr. A. von Schutz argues in the Physikalische Zeitschrift, of August 15, 1916, are supposed to be the moving electrons. When the current flows in the direction of the motion of the earth, the velocity of the electrons, relative to the æther at rest (r.t.a.), will be $\mathrm{V}, \mathrm{V}$ being equal to $v+w$, wher $v$ is the velocity of the earth (r.t.a.) and $w$ the velocity of the electrons relative to the wire (r. t. w.). When the wire is turned through 180 deg., so that the current flows with the same intensity in the direction opposit to the motion of the earth, the velocity of the electron (r.t.a.) will be $\mathrm{V}=v-w$. The same diminution of the velocity (r.t.a.) can be produced by leaving the wire at rest, but stopping the current, when $V=v$, and then restarting the current in the opposite direction, whe $\mathrm{V}=v-w$. Now the question of the magnetic field created by the current enters. If that field depende upon the velocity of the electrons r.t.a., the turning of the wire (about $180 \mathrm{deg}$.) should alter the velocity of the electrons r.t.a., and thus the magnetic field itself, an a self-induction should be set up, as in the case of the current reversal in a wire. If the motion of the electrons r.t.a. were the decisive factor, any alteration of this velocity should set up self-induction. In reality however, self-induction is only observed in one case, viz., when the velocity of the electrons relative to the wire (r.t.w.) is changed. This fact can only be explaine by the assumption that the magnetic field is induced by the motion of the electrons r.t.w., not by the motion r.t.a., for the turning of the wire does not affect the magnetic field, provided the current intensity, $i e$. , the velocity of the (negative) electrons with respect to the positive electrons, remains unchanged. Even when the current is stopped and reversed, alteration of the magnetic field and the appearance of self-induction may be prevented by bifilar winding. Thus, Schütz concludes, the magnetic field must be due to the movement of the electrons with respect to the wire, and the movement with respect to the æther is not concerned. The fundamental question whether the æther is at rest, or whether the assumption of an $æ$ ther might be abandone would remain open as before.-Engineering.

\section{Swiss Industrial and Colonial Fair}

FolLOwING the example of neighboring nations it has been decided to organize an extensive Fair in Switzerland for the purpose of attracting the attention of the trade to the various national products. The first steps were taken at Basle, and the State Council is now occupied with the question. An organization committe is appointed under the presidence of State Councillor Blocher, while M. De Praetere has the technical direction. The object of the Fair is mainty to show specimens of national products, and there will be a general exposition at Basle installed in one of the large buildings also including annexes. A good part of the space will b devoted to products manufactured in Switzerland since the war and formerly imported from foreign countries. In addition, there will be numerous smaller expositions of a special character devoted to different classes of products, and installed in various parts of town. The Fair will last two or three weeks. The object is of course not to sell upon the spot, but on the contrary to take orders and make commercial connections. Next April is the date fixed for the first of these fairs. ioNat. Anim., VII., 14; and N. H.. VIII., 76.
Foreign and Colonial Labor in the French Munitions Works

IT is already a matter of public information that the French government has decided to make use of 5,000 Chinese workmen in the establishments devoted to manufacture of war material, and not long since some 1,700 of these workmen landed at the Marseilles port More recently, two steamer loads brought the remainder of this first contingent which included 466 laborers, 238 blacksmiths, 433 masons, 165 mechanics, 279 carpenters, etc. There are also announced for an arrival in the near future at a French port of some 3,000 Annamites, who are also to be employed for industrial work, and the greater part will be engaged in the shell-loading factories. A contingent of Kabyls had been tried for this class of work, but they do not appear suited for it and had to be sent back, they being unused to anything but agriculture. Another contingent is to be brought from Senegal. According to this, the question of proper choice of Colonial labor is a matter of experiment. It is certain on the other hand, that the colonies would afford large reserves to draw upon.

\section{SCIENTIFIC AMERICAN SUPPLEMENT Founded 1876}

NEW YORK, SATURDAY, APRIL 14th, 1917 Published weekly by Munn \& Company, incorporated.
Charles Allen Munn, President; Frederick Converse Beach
Secretary: Orson D Munn Treasurer all at 233 Broadway, New York

Entered at Post Offlce of New York, N. Y., as Second Class Matter Copyright 1917 by Munn \& Co.. Inc.

The Scientific American Publications Scientiffc American Supplement (established 1876) per year $\$ 5.00$
Scientific American (established 18.15)
The combined subscription rates isd rates to foreign cou tries.

e combined subscription rates sad rates to foreign cou t
including Canda. will be furnished upon application
Remit by postal or express money orler, bank draft or check

Munn \& Co.. Inc., 233 Broadway, New York

The purpose of the Supplement is to publish the more important announcements of distinguished technologists, to digest significant articles that appear in European publications, and altogether to reflect the most advanced thought in science and industry throughout the world.

\section{Back Numbers of the Scientific American} Supplement

Supplements bearing a date earlier than January 1st, 1916, can be supplied by the H. H. Wilson Company, 39 Mamaroneck Avenue, White Plains. N. Y. Please order such back numbers from the Wilson Company. Supplements for January 1st, 1916, and subsequent issues can be supplied at 10 cents each by Munn \& Co., Inc., 233 Broadway, New York.

WE wish to call attention to the fact that we are in a position to render competent uervices in every branch of patent or trade-mark work. Our staff is composed of mechanical, electrical and chemical experts, thoroughly trained to prepare and prosecute all patent applications, irrespective of the complex nature of the subject matter involved, or of the specialized, technical, or scientific knowledge required therefor.

We also have associates throughout the world, who assist in the prosecution of patent and trade-mark applications filed in all countries foreign to the United States

Branch Office:

Munn \& Co.,

625 F Street, N. W.,

233 Broadwa

Washington, D. C

New York, N. Y.

Table of Contents

A Religious Ceremony of the Hopi Indians.-By J. Walter ${ }_{\text {Fewkes }}^{\text {PA.. }}$

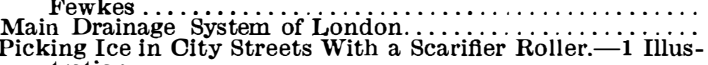

The tration....... in the Workshop..... ililustration

Europe at Turkeys Door.-By Leon Dominian.-1 iliustra-

Mechanical Difficultios in the Evolution of the steam Tur-

A bine Ammunition Depot.
Analysis of Vocal Sounds Made by Singers.

The Minimum Radiation visualiy Perceptible...... Hy Henry Norris Russell ................
Sugar Cultivation in Ceylon.
Aeroplane Ambulance Work.

Aeroplane Ambulance Work International standard for the
The Silver Voltameter as an ingent
Measurement of Electric Current._-By E. B. Rosa and

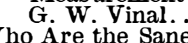

Who Are the Sane?
Oorrespondence: A N Cipher. Platinum as a Gel or Cel-
loid in the Rocks of the Pacific Coast

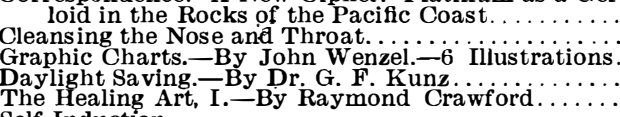

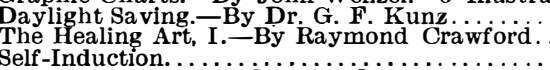

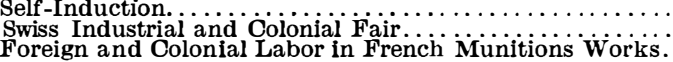

